\title{
Analisis Pengaruh Kepercayaan, Persepsi Manfaat, Dan Persepsi Kemudahan Penggunaan Terhadap Minat Beli Pada Aplikasi Tokopedia Berbasis Mobile Menggunakan Metode Technology Acceptance Model (TAM)
}

Analysis Of The Influence Of Trust, Perception Of Benefits, And Perception Of Ease Of Use To Buy Interest InMobile-Based Tokopedia Application Using Technology Acceptance Model (TAM) Method

\author{
Fatimah Nadia ${ }^{1}$ Sudiadi $^{* 2}$, Ery Hartati ${ }^{* 3}$ \\ ${ }_{1,2,3}$ Program Studi Sistem Informasi, STMIK GI MDP \\ E-mail: ${ }^{1}$ fatimahnadia03@mhs.mdp.ac.id,2 ${ }^{2}$ sudiadi@mdp.ac.id, ${ }^{3}$ ery_hartati@mdp.ac.id
}

\begin{abstract}
Abstrak
Penelitian ini bertujuan untuk menganalisis teknologi dari Tokopedia. Variabel yang dipakai dalam penelitian ini adalah Perceived Uselfulness, Perceived ease of Use, dan Behavioral Use terhadap minat beli pengguna. Penelitian ini merupakan penelitian kuantitatif dengan data deskriptif dan kausal. Teknik analisis data menggunakan Technology Acceptance Model (TAM) dengan jumlah sampel sebanyak 100 orang yang diambil datanya menggunakan kuesioner disebar melalui Google Form. Hasil dari kuesioner diolah menggunakan SPSS 23. Berdasarkan hasil analisis data yang sudah dilakukan, dapat disimpulkan bahwa dari 3 hipotesis yang diajukan semua hipotesis tersebut diterima. Variabel Perceived Usefulness mendapatkan hasil sebesar 1,880, Perceived ease of Use mendapatlan hasil sebesar 7,921, dan Behavioral Use mendapatkan hasil sebesar 0,259 artinya hanya variabel Perceived ease of use yang hanya berpengaruh secara signifikan terhadap minat beli pengguna Tokopedia. Sedangkan berdasarkan hasil dari analisis secara simultan menunjukan bahwa variabel Perceived Usefulness (X1), Perceived ease of Use (X2), dan Behavioral Use (X3) mendapatkan hasil sebesar $82,3 \%$ artinya terdapat pengaruh terhadap minat beli pengguna Tokopedia.
\end{abstract}

Kata kunci: Tokopedia, TAM, SPSS

Abstract

This study aims to analyze the technology from Tokopedia. The variables used in this research are Perceived Usefulness, Perceived ease of Use, and Behavioral Use towards users' buying interest. This research is a quantitative research with descriptive and causal data. The data analysis technique uses the Technology Acceptance Model (TAM) with a total sample of 100 people whose data is taken using a questionnaire distributed via Google Form. The results of the questionnaire were processed using SPSS 23. Based on the results of data analysis that had been carried out, it can be concluded that of the 3 proposed hypotheses, all of the hypotheses were accepted. The Perceived Usefulness variable got a result of 1,880, Perceived ease of Use got a result of 7,921, and Behavioral Use got a result of 0,259 meaning that only the Perceived ease of use variable only had a significant effect on the purchase interest of Tokopedia users. Meanwhile, based on the results of the simultaneous analysis, it shows that the variables Perceived Usefulness(X1), Perceived ease of Use (X2), and Behavioral Use (X3) get a result of $82,3 \%$, meaning that there is an influence on the purchase interest of Tokopedia users.

Keywords: Tokopedia, TAM, SPSS. 


\section{PENDAHULUAN}

Saat ini dunia telah memasuki era globalisasi sehingga kebutuhan terhadap sebuah informasi menjadi hal yang sangat penting. Seiring dengan perkembangan teknologi, sistem informasi berbasis internet banyak digunakan saat ini. Internet merupakan salah satu media yang paling ekonomis untuk digunakan oleh manusia sebagai basis system informasi. Di Indonesia sendiri, internet juga sudah dikenal dan digunakan oleh berbagai kalangan masyarakat. Perkembangan internet di Indonesia dari beberapa tahun mengalami peningkatan yang pesat. Bersamaan dengan peningkatan penggunaan internet dan teknologi, menjadi peluang bisnis baru bagi beberapa pihak yang kemudian menangkap peluang tersebut dengan menyediakan atau memanfaatkannya menjadi kegiatan bisnis. Penggunaan internet untuk aktivitas transaksi bisnis dikenal dengan istilah Electronic Commerce atau e-commerce [1]. Terdapat banyak sekali jenis-jenis ecommerce yang berkembang pesat di dunia, namun hanya terdapat beberapa jenis $e$ - commerce yang berkembang di Indonesia. Salah satu jenis $e$ commerce yang saat ini berkembang pesat di Indonesia adalah ecommerce dengan jenis marketplace. Marketplace merupakan sebuah tempat dengan aktifitas daring dimana penjual dapat membuat akun dan menjajakan barang dagangannya. Salah satu keuntungan berjualan di marketplace adalah penjual tidak perlu membuat situs atau tokoonline pribadi. Penjual hanya perlu menyediakan foto produk dan mengunggahnya yang kemudian dilengkapi dengan deskripsi produk tersebut. Selanjutnya, apabila ada pembeli yang ingin membeli produk yang ditawarkan tersebut, pihak penjual akan diberi notifikasi oleh system dari e-commerce tersebut. Beberapa marketplace yang ada di Indonesia antara lain ialah tokopedia, shopee, bukalapak, blibli.com, zalora, Tokopedia, dan sebagainya. Salah satu jenismarketplace yang cukup populer di Indonesia saat ini adalah tokopedia. Didirikan pada tahun 2009 dengan visi membangun Indonesia lebih baik melalui internet, tokopedia tumbuh sangat pesat dan menjadi marketplace terbesar di Indonesia. Berdasarkan laporan dari Katadata di tahun 2019, tercatat tokopedia sebagai salah satu ecommerce dengan jumlah pengunjung terbanyak pada kuartal III tahun 2019. Dengan demikian menandakan bahwa tokopedia merupakan ecommerce yang cukup popular dikalangan masyarakat Indonesia saat ini. Tokopedia sendiri merupakan online marketplace yang memungkinkan setiap orang dan pemilik bisnis di Indonesia untuk membuka dan mengurus toko online mereka secara mudah dan bebas biaya pada aplikasi tokopedia, sekaligus memberikan pengalaman jual beli secara online dengan aman dan nyaman. Selain itu tokopedia juga menyediakan berbagai macam mall online yang merupakan tempat berkumpulnya toko-toko online terpercaya di seluruh Indonesia. Pengguna tokopedia atau yang sering disebut toppers dapat membandingkan harga dari berbagai toko yang terdapat pada tokopedia, sehingga memungkinkan toppers untuk mendapatkan produk yang diinginkan dengan harga yang lebih murah. Namun masih banyak masyarakat yang khawatir dalam menggunakan transaksi jual beli secara online dikarenakan saluran transaksi pemasaran yang masih tergolong baru. Ecommerce lebih mengandung ketidakpastian dan risiko dibandingkan dengan transaksi yang dilakukan secara konvensional. Hal ini yang kemudian menjadi pertimbangan bagi masyarakat untuk melakukan pembelian secara online. Membeli secara online dapat dipengaruhi oleh Efisiensi untuk pencarian (waktu) cepat, mudah dalam penggunaan, dan usaha pencarian mudah), value (harga bersaing dan kualitas baik); dan interaksi (informasi, keamanan, load time, dan navigasi) [2]. Sedangkan kepercayaan (trust) menjadi dasar terhadap transaksi bagi penjual dan pembeli yang membuat konsumen memiliki harapan besar untuk puas terhadap hubungan tukar menukar tersebut persentase ketidakpercayaan masyarakat terhadap jual beli secara online masih cukup tinggi, hal ini ditunjukkan melalui beberapa poin, contohnyaadalah barang yang tidak sesuai dengan keinginan. Hal ini menjadi sebuah ketimpangan karena tidak sesuai dengan perkembangan ecommerce di Indonesia [3]. Trust berkaitan dengan keyakinan bahwa pihak yang dipercaya akan memenuhi komitmennya. Kepercayaan masyarakat terhadap $e$ - commerce merupakan salah satu faktor kunci melakukan kegiatan jual beli secara online [4]. Di tokopedia sendiri pengguna atau yang biasa disebut toppers yang ingin 
membeli produk dari salah satu toko online yang terdapat di tokopedia diharuskan untuk membuat akun di tokopedia. Dalam pembuatan akun tersebut, toppers harus mencantumkan data pribadi berupa nama lengkap, nomor $\mathrm{hp}$, email, dan lain sebagainya. Keharusan pendaftaran dengan cara mencantumkan informasi pribadi terkadang membuat sebagian orang enggan untuk melakukannya. Lebih dari $69 \%$ dari pembeli internet membatasi pembelian online mereka karena kekhawatiran yang berkaitan dengan privasi dan keamanan informasi pribadi mereka [5]. Sehingga dapat diartikan bahwa keamanan merupakan salah satu faktor penting yang dapat mempengaruhi keputusan pembelian secara online. Selain masalah kepercayaan dijelaskan bahwa adanya sebagian masyarakat yang merasa bahwa berbelanja online tidak cukup praktis dan ada juga beberapa masyarakat yang tidak mengetahui cara berbelanja online. Hal tersebut sangat dipengaruhi oleh teori sistem informasi, salah satunya adalah TAM (Technology Acceptance Model). TAM adalah teori sistem informasi yang dirancang untuk menjelaskan bagaimana pengguna mengerti dan menggunakan sebuah teknologi informasi. Tujuan TAM adalah untuk memberikan dasar penelusuran pengaruh faktor eksternal terhadap kepercayaan, sikap, dan tujuan pengguna [6]. Persepsi manfaat adalah sejauh mana seseorang percaya bahwa menggunakan suatu teknologi akan meningkatkan kinerjanya [7]. Kemudahan (ease) bermakna tanpa kesulitan atau tidak memerlukan usaha keras saat menggunakan teknologi tersebut. Demikian persepsi mengenai kemudahan penggunaan teknologi ini merujuk pada keyakinan individu bahwa sistemteknologi informasi yang digunakan tidak dibutuhkan usaha yang besar pada saat pengoperasian. Berdasarkan penelitian yang telah dilakukan oleh Davis dapatdikatakan bahwa dalam mengembangkan sebuah sistem informasi perlu dipertimbangkan factor kebermanfaatan dan kemudahan dari pengguna sistem informasi. Berdasarkan latar belakang yang telah diuraikan di atas, muncul masalah apakah kepercayaan, manfaat, dan kemudahan berpengaruh terhadap keputusan pembelian secara online di tokopedia. Berdasarkan masalah tersebut, penulis tertarik melakukan penelitian yang berjudul "Analisis Pengaruh Kepercayaan, Persepsi Manfaat, dan Persepsi Kemudahan terhadap Minat Beli pada Aplikasi Tokopedia Berbasis Mobile Menggunakan Metode Technology Accaptance Model (TAM)".

\section{METODE PENELITIAN}

Dalam melakukan penelitian ini untuk mendapatkan data serta informasiadapun metode yang digunakan, yaitu dengan kuisioner dan studi literatur.

a. Kuesioner

Kuesioner merupakan teknik pengumpulan data yang dilakukan dengan cara memberi seperangkat pertanyaan atau pernyataan tertulis kepada responden untuk dijawab. Kuesioner juga cocok digunakan bilajumlah responden cukup besar dan tersebar di wilayah yang luas. Kuesioner dapat berupa pertanyaan/pernyataan tertutup atau terbuka dapat diberikan kepada responden secara langsung atau dikirimkanmelalui pos atau internet.

b. Studi Literatur

Studi literatur merupakan penelitian yang dilakukan oleh peneliti dengan mengumpulkan sejumlah buku buku, majalah yang berkaitan dengan masalah dan tujuan penelitian. Teknik ini dilakukan dengan tujuan untuk mengungkapkan berbagai teori-teori yang relevan dengan permasalahan yang sedang dihadapi/diteliti sebagai bahan rujukan dalam pembahasan hasil penelitian.

\subsection{Tahapan Penelitian}

Gambar 1 berikut adalah tahapan penelitian yang dilakukan dalam penelitian: 


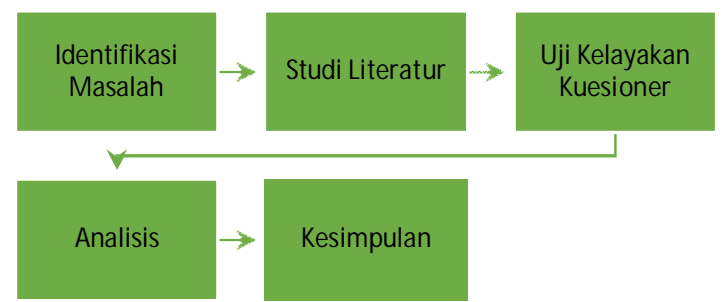

Gambar 1. Tahapan Penelitian

Beberapa tahapan - tahapan yang dilakukan pada analisis ini dimulai dengan menentukan permasalahan pada kasus yang akan dianalisis denganTokopedia sebagai objeknya. Kemudian langkah selanjutnya penulis menentukan judul yang sesuai untuk analisis. selanjutnya dilakukan pencarian studi literatur untuk mencari referensi dalam penulisan judul yang berkaitan dengan penelitian yang dilakukan. Setelah itu mengidentifikasi jumlah populasi pengguna Tokopedia yang akan dianalisis, dan ditentukan jumlah sampelnya. Kemudian penulis mulai menyusun kuesioner yang sesuai dan berhubungan dengan kasus dan disebarkan kepada pengguna Tokopedia melalui Google Form dan dilakukan secara random. Setelah dilakukan penyebaran kuesioner dan dilakukan perhitungan untuk mendapatkan hasil kuesioner dengan dilakukan perhitungan analisis deskriptif, pengujian persyaratan analisis, uji validitas, uji reliabilitas dan uji hipotesis dengan melakukan uji t dan uji $\mathrm{f}$ pada variabel TAM dengan menggunakan aplikasi olah data SPSS. Kemudian menarik kesimpulan dari hasil yang didapatkan dalam penelitian.

\subsection{Populasi dan Sampel}

Populasi penelitian ini adalah pengguna aplikasi Tokopedia. Jumlah populasi dalam penelitian ini tidak diketahui secara pasti. Adapun jumlah pengguna aplikasi Tokopedia didapatkan sebanyak 100 responden. Sampel adalah bagian dari jumlah dan karakteristik yang dimiliki oleh populasi. Bila populasi besar, dan peneliti tidak mungkin mempelajarisemua yang ada pada populasi, misalnya karena keterbatasan dana, tenaga dan waktu, maka peneliti dapat menggunakan sampel yang diambil dari populasi itu. Apa yang dipelajari dari sampel itu, kesimpulannya akan dapat diberlakukan untuk populasi. Untuk itu sampel yang diambil dari populasi harus betulbetul representative (mewakili).

\subsection{Penentuan Sampel}

Penentuan banyaknya sampel dalam penelitian ini menggunakan rumus Rao Purba [7]. Tingkat kesalahan sebesar 10\% dan tingkat keyakinan sebesar $95 \%$.

Keterangan:

$$
\begin{aligned}
& n=\frac{Z^{2}}{4(\text { Moe })^{2}} \\
& n=\frac{1,96^{2}}{4(0,1)^{2}} \\
& n=96,04 \approx 100
\end{aligned}
$$

$\mathrm{n}=$ Ukuran sampel

$\mathrm{Z}=$ skor pada tingkat signifikan tertentu

Moe $=$ margin of error, tingkat kesalahan maksimum yang dapatditoleransi

Tingkat kesalahan maksimum yang dapat ditoleransi pada penelitian ini ditetapkan sebesar 0,10 atau $10 \%$ sehingga tingkat kepercayaan dalam penentuan sampel yang digunakan adalah $95 \%$ atau $\mathrm{z}=1,96$. Nilai tingkat keyakinan $95 \%$ atau $\mathrm{z}=1,96$ adalah tingkat keyakinan yang paling sering digunakan. Tingkat keyakinan 95\% atau $\mathrm{z}=1,96$ memberikan keseimbangan antara presisi dan reliabilitas. Perhitungan tersebut menunjukan bahwa sampel yang di ambil dalam penelitian ini adalah sebanyak 100 responden. 


\subsection{Variabel Penelitian}

Berdasarkan studi literatur, diperoleh variabel dan indikator yang digunakan penelitian merujuk pada jurnal penelitian sebelumnya seperti pada Tabel 1 .

Tabel 1. Variabel dan Indikator Penelitian

\begin{tabular}{|c|c|c|}
\hline Variabel & Kode & Indikator \\
\hline \multirow{3}{*}{ Perceived usefulness (X1) } & PU1 & $\begin{array}{l}\text { Penggunaan Tokopedia memudahkan saya } \\
\text { dalam belanja online }\end{array}$ \\
\hline & PU2 & $\begin{array}{l}\text { Penggunaan Tokopedia meningkatkanefisiensi } \\
\text { belanja online }\end{array}$ \\
\hline & PU3 & $\begin{array}{l}\text { Informasi produk tersedia saat saya } \\
\text { membutuhkan }\end{array}$ \\
\hline \multirow{3}{*}{$\begin{array}{l}\text { Perceived ease of use } \\
\text { (X2) }\end{array}$} & PEOU1 & Tokopedia mudah untuk digunakan \\
\hline & PEOU2 & Tokopedia cukup fleksibel untuk digunakan \\
\hline & PEOU3 & $\begin{array}{l}\text { Tidak mengalami kesulitan saat } \\
\text { menggunakan Tokopedia }\end{array}$ \\
\hline \multirow{3}{*}{ Behavioral Use (X3) } & ITU1 & Tokopedia cukup nyaman untuk digunakan \\
\hline & ITU2 & $\begin{array}{l}\text { Proses aktual dari penggunaan Tokopedia } \\
\text { menyenangkan }\end{array}$ \\
\hline & ITU3 & Tokopedia menyenangkan untuk digunakan \\
\hline
\end{tabular}

\subsection{Hipotesis Penelitian}

Penelitian ini menggunakan desain kausal yang bertujuan untuk menganalisis hubungan antara satu variabel dengan variabel lainnya. Desain kausal digunakan untuk menganalisis secara empiris variabel- variabel yang berpengaruh terhadap minat beli, yakni variabel Perceived Uselfulness, Perceived ease of Use, dan Behavioral Use terhadap minat beli pengguna. Gambar 2 berikut adalah hipotesis penelitian berdasarkan model TAM.

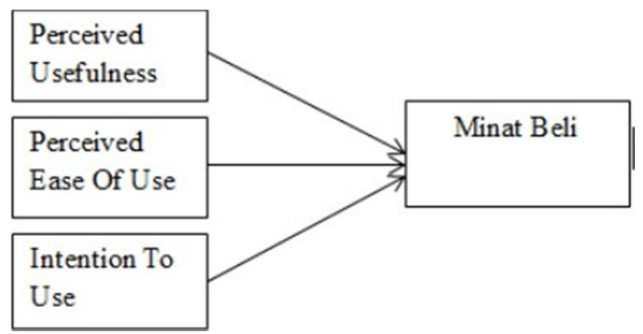

Gambar 2. Model Penelitian

Untuk mengukur minat beli terhadap penerapan suatu sistem informasi dalam penelitian ini menggunakan model TAM. Terdapat lima faktor yang dapat mempengaruhi minat beli terhadap penerapan suatu system. Sehingga, dirumuskan empat hipotesis dalam penelitian ini, yaitu:

X1: Persepsi kemudahan sistem perceived usefulness (PU) berpengaruh positif terhadap minat beli pengguna Tokopedia.

$\mathrm{X}$ 2: Persepsi perceived ease of use (PEOU) berpengaruh positif terhadapminat beli pengguna Tokopedia.

X3: Persepsi kemudahan sistem Behavioral Use (ITU) berpengaruh positifterhadap minat beli pengguna Tokopedia.

Y: Minat beli pengguna Tokopedia 


\section{HASIL DAN PEMBAHASAN}

\subsection{Profil Responden}

Berdasarkan kuesioner yang telah disebarkan melalui link google form kepada 100 responden pengguna aplikasi Tokopedia, maka di dapatkan lah responden dengan latar belakang status yang berbeda berdasarkan instansi, semester dan program studi.

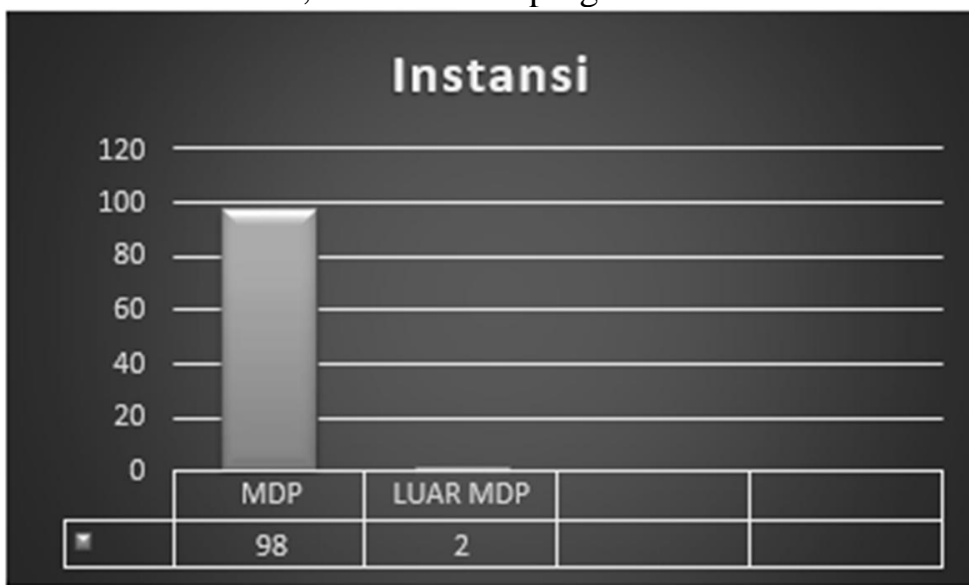

Gambar 3. Instansi

Berdasarkan gambar 3, menunjukkan bahwa dari 100 data responden yang digunakan dalam analisis ini, sebagian besar didominasi oleh responden mahasiswa MDP sebanyak 98 orang dengan persentase $98 \%$, sedangkan sisanya merupakan responden luar MDP dengan persentase $2 \%$.

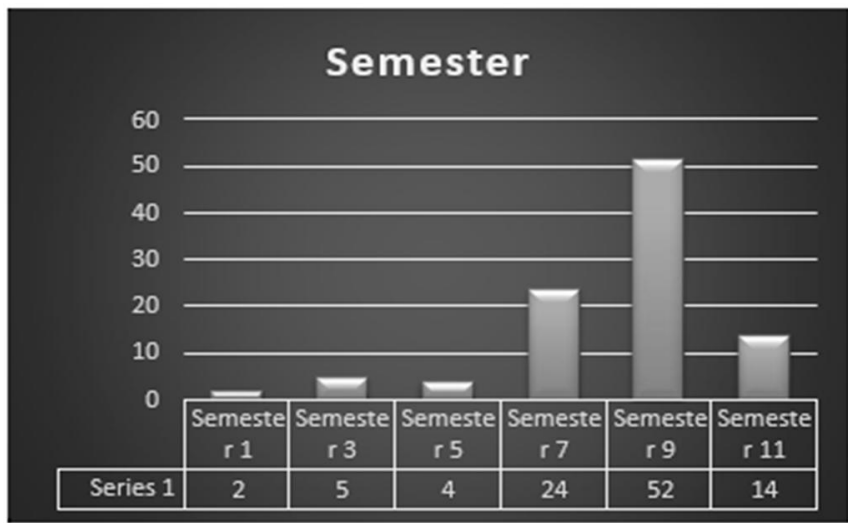

Gambar 4. Semester

Dari gambar 4, menunjukkan bahwa dari 100 data responden yang digunakan dalam analisis ini, sebagian besar didominasi oleh responden semester 9 (Sembilan) sebanyak 52 orang dengan persentase 51,5\% selanjutnya diikuti dengan semester 7 (Tujuh) sebanyak 24 orang dengan persentase $26 \%$ kemudian semester 1,3,5 dan 11 . 


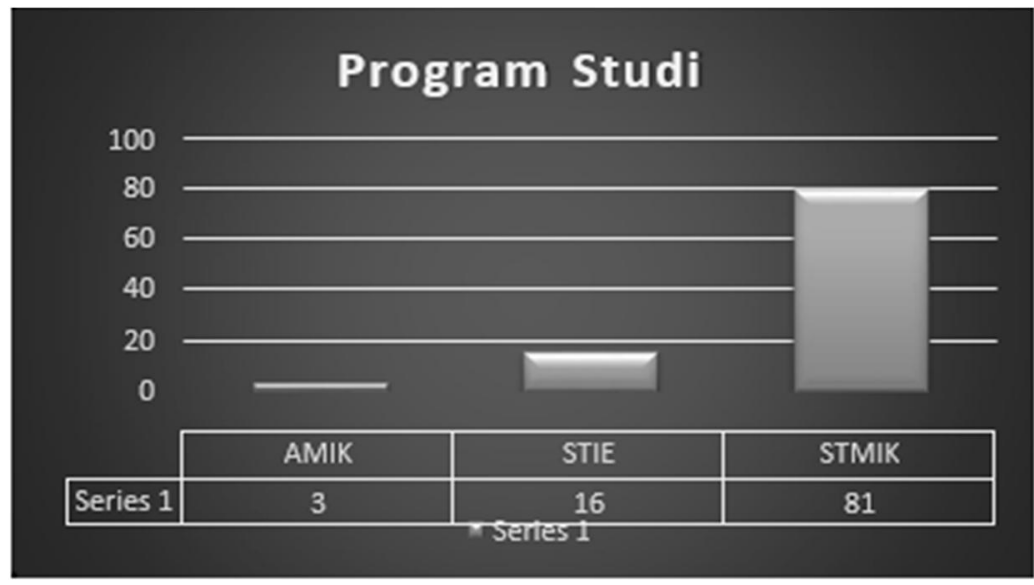

Gambar 5. Program Studi

Dari gambar 5 dapat diketahui bahwa program studi responden paling banyak berasal dari STMIK sebanyak $81 \%$ orang kemudian diikuti dengan STIE sebanyak $16 \%$ orang dan sisanya adalah AMIK.

\subsection{Uji Validitas dan Reliabilitas}

Pengujian validitas dilakukan untuk memastikan seberapa baik instrumen digunakan untuk mengukur konsep yang seharusnya diukur, untuk menguji validitas konstruk yang dilakukan dengan caramengorelasikan antara skor butir pertanyaan dengan skor totalnya. Hasil dari perhitungan uji validitas ditunjukkan Tabel 2.

Tabel 2. Uji Validitas

\begin{tabular}{|l|l|l|l|l|}
\hline Indikator & Rtabel & rhitung & Signifikan & Keterangan \\
\hline PU1 & 0,195 & 0,895 & 0,000 & Valid \\
\hline PU2 & 0,195 & 0,869 & 0,000 & Valid \\
\hline PU3 & 0,195 & 0,811 & 0,000 & Valid \\
\hline PU4 & 0,195 & 0,791 & 0,000 & Valid \\
\hline PU5 & 0,195 & 0,854 & 0,000 & Valid \\
\hline PU6 & 0,195 & 0,872 & 0,000 & Valid \\
\hline PU7 & 0,195 & 0,876 & 0,000 & Valid \\
\hline PE1 & 0,195 & 0,850 & 0,000 & Valid \\
\hline PE2 & 0,195 & 0,861 & 0,000 & Valid \\
\hline PE3 & 0,195 & 0,869 & 0,000 & Valid \\
\hline PE4 & 0,195 & 0,832 & 0,000 & Valid \\
\hline PE5 & 0,195 & 0,867 & 0,000 & Valid \\
\hline PE6 & 0,195 & 0,847 & 0,000 & Valid \\
\hline PE7 & 0,195 & 0,812 & 0,000 & Valid \\
\hline BU1 & 0,195 & 0,835 & 0,000 & Valid \\
\hline BU2 & 0,195 & 0,839 & 0,000 & Valid \\
\hline BU3 & 0,195 & 0.845 & 0,000 & Valid \\
\hline BU4 & 0,195 & 0.839 & 0,000 & Valid \\
\hline BU5 & 0,195 & 0.864 & 0,000 & Valid \\
\hline BU6 & 0,195 & 0.825 & 0,000 & Valid \\
\hline Y1 & 0,195 & 0.896 & 0,000 & Valid \\
\hline
\end{tabular}




\begin{tabular}{|l|l|l|l|l|}
\hline Y2 & 0,195 & 0.889 & 0,000 & Valid \\
\hline Y3 & 0,195 & 0.880 & 0,000 & Valid \\
\hline Y4 & 0,195 & 0.794 & 0,000 & Valid \\
\hline Y5 & 0,195 & 0.883 & 0,000 & Valid \\
\hline Y6 & 0,195 & 0.895 & 0,000 & Valid \\
\hline
\end{tabular}

Dari hasil uji validitas variabel Perceived Usefulness, Perceived Ease Of Use, dan Behavioral Use dengan menggunakan SPSS terhadap 100 responden dapat diambil kesimpulan bahwa semua item pernyataan tersebut memiliki nilai rhitung > rtabel dan nilai signifikansi pvalue lebih kecil dari 0,05 . Sehingga semua item pernyataan tersebut dapat digunakan dalam penelitian ini (valid). Hasil dari perhitungan uji reliabilitas dapat dilihat pada Tabel 3.

Tabel 3. Uji Reabilitas

\begin{tabular}{|l|c|c|c|}
\hline \multicolumn{1}{|c|}{ Variabel } & Cronbach Alpha & Standar Reliabilitas & Keterangan \\
\hline Perceived Usefulness & 0,937 & 0,7 & Reliabel \\
\hline Perceived Ease Of Use & 0,935 & 0,7 & Reliabel \\
\hline Behavioral Use & 0,917 & 0,7 & Reliabel \\
\hline Minat beli pengguna & 0,938 & 0,7 & Reliabel \\
\hline
\end{tabular}

Dari hasil uji reliabilitas semua variabel, diperoleh nilai-nilai Cronbach Alpha dari semua variabel penelitian ini menunjukkan lebihbesar dari nilai 0,7 maka demikian jawabanjawaban responden dari variabel-variabel penelitian tersebut reliabel, sehingga dapat digunakan untuk penelitian selanjutnya.

\subsection{Uji Hipotesis}

\subsubsection{Hasil uji $t$ (Parsial)}

Uji t dilakukan untuk menguji tingkat signifikansi pengaruh variabel independen terhadap variabel dependen secara parsial. Tingkat signifikansi yang digunakan sebesar 5\%. Berdasarkan hasil analisis didapatkan hasil seperti pada Tabel 2 dan 3 yang menggunakan SPSS, hasil pengujian secara parsial adalah sebagai berikut:

Berdasarkan gambar hasil pengujian secara parsial adalah sebagai berikut:

1. Berdasarkan hasil uji t (parsial) pada model regresi, diperoleh nilait hitung 1.880 Artinya dapat disimpulkan bahwa secara parsial variabel Perceived Usefulness berpengaruh signifikan terhadap Minat beli pengguna. 
2. Berdasarkan hasil uji t (parsial) pada model regresi, diperoleh nilait hitung sebesar 7.921 artinya dapat disimpulkan bahwa secara parsial variabel Perceived Ease Of Use berpengaruh signifikan terhadap Minat beli pengguna.

3. Berdasarkan hasil uji t (parsial) pada model regresi, diperoleh nilait hitung sebesar 0.259 artinya dapat disimpulkan bahwa secaraparsial variabel Behavioral Use tidak berpengaruh signifikan terhadap Minat beli pengguna.

\subsubsection{Hasil uji $F$}

Uji $\mathrm{F}$ adalah untuk menunjukkan apakah variabel independen yang dimasukkan dalam model mempunyai pengaruh secara bersama-sama terhadap variabel dependen. Pengujian dilakukan dengan tingkat signifikansi $5 \%$ atau 0,05 . Berdasarkan hasil analisis didapatkan hasil sebagai berikut:

Tabel 4. Hasil uji F

\begin{tabular}{|l|l|r|r|r|r|c|}
\hline \multicolumn{7}{|c|}{ ANOVA $^{\text {a }}$ (uji F) } \\
\hline \multicolumn{2}{|c|}{ Model } & Sum of Squares & df & Mean Square & F & Sig. \\
\hline \multirow{3}{*}{1} & Regression & 1028,258 & 3 & 342,753 & 66,388 & $0,000^{\mathrm{b}}$ \\
\cline { 2 - 7 } & Residual & 490,469 & 95 & 5,163 & & \\
\cline { 2 - 7 } & Total & 1518,727 & 98 & & & \\
\hline
\end{tabular}

Berdasarkan gambar di atas dapat diperoleh nilai $\mathrm{F}$ hitung sebesar 66,388 dengan taraf signifikansi sebesar 0,000. Ini menunjukkan bahwa taraf signifikansi $\mathrm{F}$ hitung lebih kecil dari nilai tingkat signifikansi 0,05. Artinya bahwa variabel Perceived Usefulness, Perceived Ease Of Use, danBehavioral Use secara bersama-sama mempunyai pengaruh yang positif dan signifikan terhadap Minat beli pengguna.

\subsubsection{Hasil Uji Koefisien Determinasi $\left(R^{2}\right)$}

Nilai koefisien determinasi ditunjukkan oleh nilai $\mathrm{R}^{2}$ dari model regresi digunakan untuk mengetahui besarnya variabilitas variabel dependen yang dapat dijelaskan oleh variabelvariabel bebasnya. Berdasarkan hasil analisis didapatkan hasil sebagai berikut:

Tabel 5. Hasil Uji Koefisien Determinasi

\begin{tabular}{|c|c|c|c|c|}
\hline \multicolumn{5}{|c|}{ Model Summary $^{\mathbf{b}}$} \\
\hline Model & $\mathbf{R}$ & R Square & $\begin{array}{c}\text { Adjusted } \\
\text { R Square }\end{array}$ & $\begin{array}{c}\text { Std. Error of } \\
\text { The Estimate }\end{array}$ \\
\hline 1 & $0,823^{\text {a }}$ & 0,677 & 0,667 & 2,272 \\
\hline \multicolumn{4}{|l|}{ a. Predictors: (Constant), Behavioral Use, Ease Of Use, Usefullness } \\
\hline
\end{tabular}

Berdasarkan tabel diatas menunjukkan bahwa nilai $\mathrm{R}^{2}$ sebesar $0.68 \%$ yang berarti bahwa variabilitas variabel Minat beli pengguna yang dapat dijelaskan oleh variabel Perceived Usefulness, Perceived Ease Of Use, dan Behavioral Use sebesar 82,3\%. Sedangkan sisanya sebesar $17,7 \%$ dijelaskan oleh faktor lain yang tidak disertakan dalam penelitian ini.

\subsection{Pembahasan}

1. Variabel Perceived Usefulness berpengaruh terhadap tingkat minat beli pengguna Tokopedia.

Mengukur minat beli pengguna ditinjau dari sisi Perceived Usefulness dari aplikasi Tokopedia. Variabel kepercayaan memiliki hubungan yang signifikan terhadap minat beli pengguna Tokopedia, berdasarkan hasil dari uji t, diperoleh nilai t statistik sebesar 1,880 
Artinya variabel Perceived Usefulness berpengaruh terhadap minat beli pengguna aplikasi Tokopedia.

2. Variabel Perceived Ease Of Use berpengaruh terhadap tingkat minat beli pengguna aplikasi Tokopedia.

Mengukur minat beli pengguna dari sisi Perceived Ease Of Use yang disediakan oleh aplikasi Tokopedia. Pada variabel persepsi manfaat hasil berdasarkan uji $\mathrm{t}$, diperoleh nilai $\mathrm{t}$ statistik sebesar 7,921 Artinya variabel Perceived Ease Of Use berpengaruh terhadap minat beli pengguna aplikasi Tokopedia.

3. Variabel Behavioral Use berpengaruh terhadap tingkat minat beli pengguna Tokopedia.

Mengukur minat beli pengguna dari sisi Behavioral Use program aplikasi Tokopedia itu sendiri dimana variabel Behavioral Use berdasarkan hasil uji t, diperoleh nilai t statistik sebesar 0,259 artinya variabel Behavioral Use tidak berpengaruh secara sig terhadap minat beli pengguna aplikasi Tokopedia.

\section{KESIMPULAN DAN SARAN}

Kesimpulan yang diperoleh dari hasil penelitian adalah sebagai berikut: Berdasarkan hasil analisis data yang sudah dilakukan, dapat disimpulkan bahwa dari 3 hipotesis yang diajukan semua hipotesis tersebut diterima. Hasil dari analisis secara parsial menunjukan bahwa variabel Constant 1,344 berdasarkan hasil uji variabel Perceived Usefulness (X1), variabel Perceived Ease of Use (X2) dan variabel Behavioral Use (X3), berpengaruh secarasignifikan terhadap minat beli pengguna Tokopedia. Sedangkan berdasarkanhasil dari analisis secara simultan menunjukan bahwa variabel variabel Perceived Usefulness (X1), variabel Perceived Ease Of Use (X2) dan variabel Behavioral Use (X3), mendapatkan hasil sebesar $82,3 \%$ terhadap minat beli pengguna Tokopedia.

Penulis menyadari masih banyak kekurangan dalam melakukan penelitian ini. Adapun saran yang dapat diberikan oleh penulis adalah:

1. Saran perbaikan untuk aplikasi Tokopedia agar dapat memperhatian aplikasi dari sisi Perceived Usefulness dan Behavioral Use yang mendapatkan hasil lebih kecil dibandingkan Perceived Ease Of Use, yang berarti pengguna merasa bahwa aplikasi Tokopedia kurang memberikan perhatian pada sisi Perceived Usefulness (kemudahan penggunaan) dan sisi Behavioral Use (kecendrungan perilaku menggunakan teknologi) bagi pengguna aplikasi Tokopedia itu sendiri.

2. Untuk peneliti selanjutnya diharapkan dapat menggunakan metode yang berbeda agar bisa dibandingkan dengan penelitian yang sudah dilakukan sebelumnya, atau menggunakan metode yang sama namun dengan kasus yang berbeda dan dengan jumlah populasi yang lebih banyak.

3. Untuk penelitian selanjutnya dapat menggunakan teknik pengambilan sampling yang berbeda dari penelitian yang dilakukan ini dan menggunakan sampel dengan jumlah yang sudah diketahui jumlahpastinya. Karena mungkin dari teknik pengambilan sampling dan sampel yang sudah diketahui jumlahnya yang akan dilakukan dapat mempengaruhi hasil dari penelitian yang dilakukan.

\section{DAFTAR PUSTAKA}

[1] Munir Fuady. 2002, Pengantar Hukum Bisnis, PT. Citra Aditya Bakti, Bandung.

[2] Robbins dan Kumar. 1995, Buku Ajar Patologi 1. Edisi 4, EGC. 290- 293, Jakarta. 
[3] Della Alvialli Suwanto. 2013, Survey Tentang Pemahaman dan Sikap Siswa Terhadap Narkoba atau Napza di Kalangan Remaja Universitas Indonesia.

[4] Sugiyono, 2011, Metode Penelitian Kuantitaif Kualitatif dan $R \& B$, Alfabeta, Bandung.

[5] Adnyasuari, P. A. S. and Darma, G. S. 2017, 'Technology Acceptance Model and ESatisfaction in Mobile Banking', Jurnal Manajemen dan Bisnis, 14(2), pp. 1-3.

[6] Laudon, J., dan Laudon, K. C. 1998, Essential of Management Information System, Prentice Hall, New Jersey.

[7] Rao, Purba. 2006, Measuring Consumer Perception Through Factor Analysis, The Asian Manager (February-March). 